\title{
Personal and Social Values in Primary Grade Children's Books
}

\begin{tabular}{|c|c|}
\hline \multicolumn{2}{|c|}{ Kirşehir Ahi Evran University, Education Faculty, Kirsehir, Tuyrkey } \\
\hline Article history & One requirement of realizing the aims of Turkish National Education is \\
\hline $\begin{array}{l}\text { Received: } \\
14.08 .2018\end{array}$ & $\begin{array}{l}\text { educating individuals that adopt the values of Turkish Nation. Families, } \\
\text { educational institutions, and teaching materials have important roles to }\end{array}$ \\
\hline $\begin{array}{l}\text { Received in revised form: } \\
26.12 .2018\end{array}$ & $\begin{array}{l}\text { raise individuals who adopt social values and put them into practice. One } \\
\text { of the important materials is written children books. In this context, the } \\
\text { aim of the study is to determine the personal and social values dealt with }\end{array}$ \\
\hline $\begin{array}{l}\text { Accepted: } \\
09.01 .2019\end{array}$ & $\begin{array}{l}\text { in primary grade children's books. One of the qualitative methods, } \\
\text { document analysis method was used in the study. Universe of the study }\end{array}$ \\
\hline Key : & was consisted of written children's books of elementary grades. Sample \\
\hline $\begin{array}{l}\text { Value, value education, } \\
\text { children's books, elementary } \\
\text { education. }\end{array}$ & $\begin{array}{l}\text { was consisted of children books that are sold in the city center of } \\
\text { Kurşehir. The sample a total of } 210 \text { children from domestic and foreign } \\
\text { authors who were selected by random sampling among the children's } \\
\text { books belonging to different publishing house offered for sale in book } \\
\text { stories in the city center of Kirşehir were created from the book. To } \\
\text { collect data, "Values Control List" was developed and used by the } \\
\text { researcher. Study findings showed that the children's books commonly } \\
\text { include individual values are "responsibility, love, goodness, diligence, } \\
\text { animal love and trust" and social values are "friendship, helpfulness and } \\
\text { unity of family". The least mentioned individual values are "cleanliness, } \\
\text { being patient, frugality, loyalty, being tactful and morality" and social } \\
\text { values are "patriotism, peace, empathy, love of nature and freedom". }\end{array}$ \\
\hline
\end{tabular}

\section{Introduction}

Children's literature that appeals to children between the ages of 2 and 14 covers all written and oral pieces related to their imagination, feelings and thoughts (Tür \& Turla, 1999). Beginning in early childhood, children's books play a critical role in developing individual values concerning life and human reality. Children's books recreate various characters through the power of expression. Fictions based on characters and their relationships present a set of experiences related to children's knowledge of humanity, nature and life (Sever, 2007).

Children's literature includes all the written and verbal pieces related to children's imaginations, emotions and thoughts in childhood. These pieces, which can be written in various forms, are influential just like pieces written for adults such as fairy tales, stories, novels, journals, biographic pieces, travel writings, poems, writings about science and nature etc. These can all be included in this perspective (Oğuzkan, 1979). According to Sever (2007), children's literature is the general title of all pieces which covers a period starting

\footnotetext{
*Correspondence: ayfersahin1@gmail.com, ORCID ID: /0000-0001-9903-1445
} 
from early childhood and continuing during adolescence, and which enriches children's world of emotions and thought with linguistic and visual stimuli including artistic value and in accordance with their language development and understanding level.

Şirin (2007) defines children's literature as “...a childish literature which is created to contribute to children's growth and development, imaginations, emotions, thoughts and sensitiveness, and to enable them to enjoy while learning." Books are one of the vital factors influencing agents' intellectual and spiritual developments (Güleç \& Gönen, 1997). Temizyürek (2003, p. 161) addresses children's literature as written and verbal literacy pieces which children read or listen to with joy, which appeal to children's dream world, have high qualities and aesthetics, in accordance with children's vocabulary, help children improve their native language, contain both national and universal values and contribute to children's psycho-social developments."

\section{Child Books, Values and Literature}

Children's literature consists of 'children' and 'literature' variables, but it is an artistic framework creating an integrity through using both with different perspectives. Inherently, children's literatures have fields of knowledge which need to be nurtured. These fields could be relationship with society, individual, nature, philosophy and universe, and they also comprise the dimensions of children's literature (Güleryüz, 2003). In this sense, the primary goal of children's literature is to provide sources so as to create a curious and wise population who can think, question, establish identifications, search and criticize (Kutlu, 2011).

The general aims of children's literature during childhood and first years of primary education can be listed as helping them gain skills towards critical and creative thinking, expressing themselves, talking appropriately, establishing effective communication with others and empathizing, developing literal and aesthetic values, and culture of reading book and enabling them to read voluntarily.

A value can be defined as "the integration of whole material and nonmaterial components covering a nation's social, cultural, economic and scientific values" (Turkish Language Association [TLA], 2011). This is an abstract unit of measure to indicate the importance of concrete or abstract phenomenon, and is a concept emphasizing the current situation and significance of living and non-living things, events and notions (Köknel, 2007). It is also a rational pattern that can be compared with cultural or social structures (Kluckohn, 1962).

Value is the phenomenon which gives meaning to human life and gains individuals a real identity. Just like morals education, value addresses aims to change students' attitudes. Hence, it is of a different perspective than their cognitive part. Students are to be expected to internalize the given information so as to realize a change in attitudes, which is all about the process of accepting and embracing knowledge (Y1lmaz, 2003).

As a criteria, "...value determines the difference between what it is and what it should be, and it is always acknowledged as a positive or negative thing," (Cevizci, 2002, p. 248). According to Theodorson and Theodorson $(1979$, p. 455), value is "...generalized abstract behavior patterns created by strong emotional bonds among a group of people, and it provides basic standards to assess and judge the importance of social phenomenon and specific acts and goals." To psychologists, value is acknowledged as "belief" (Güngör, 1993, p. 18). Bilgin (2003, p. 80) thinks that "...value is the belief about what is good and what is bad." For Güngör (1998) "value is the belief concerning whether something is desirable or not." 
Values are the common thoughts about what is socially right or not, and directly affect human behavior (Kornblum 1994; Özgüven, 1994; Halstead and Taylor 2000; Carr and Skinner 2009). Social values produced by societies over time are society's cultural products. Social values are just like society's identities and finger prints, and comprise the basics of human behaviors (Canatan, 2008, p. 64). Values facilitate individual adaptation to society, and agents learn values from family and their immediate surroundings through modeling the written and visual materials or reading (language) (Şen, 2008, p. 768).

To educate children in accordance with commonly accepted values in society is the duty of both family and schools. However, for a young person, what is wrong or right in behaviors or on which basic values the young construct their lives are still not in the content of course programs or curriculums. "According to which moral values children should be raised is a vital issue which both family, school and other social institutions should discuss together (Dilmaç, 2002, p. 3). "The goal of the education system is to train students as individuals who" can adapt to all possible changes and developments in globalization and can easily assimilate national and universal values and respect them," (Kan, 2009, p. 896).

Since literature addresses agents' affective worlds, it can be a tool to teach many emotions and thoughts. Especially during recent years, the increase in violence, substance addiction and crime rates among children make the need for many forgotten values a current issue. Among institutions which teach values, schools deliver values through curriculums (Sönmez, 2011).

One of the conditions of realizing the aims of Turkish National Education is to raise individuals to adopt the values of the Turkish nation. Families, educational institutions and any educational materials are of important duties so as to raise individuals assimilating and practicing social values. One of these important educational materials are children's books. The contents, characters and messages in children's books are of vital and critical importance in order to raise individuals with Turkish national values. However, in a literature review, it is revealed that the number of wide-ranging studies examining the values which can be used in values education can provide children with model lives and rich stimulus by enriching children's experiences and personal, social, cultural and aesthetic developments, is quite limited.

In this context, the aim of the study is to determine the personal and social values dealt with in primary grade children's books. Within this perspective, the answers to the following questions were sought:

- What are the personal values included in primary grade children's books?

- What are the social values included in primary grade children's books?

\section{Method}

In the study, document analysis technique was used as qualitative research methods. "One of the important sources of information in qualitative research is the document analysis" (Creswell, 2012, p.223). "Document analysis includes the examination of written materials containing information about the goal of research" (Yıldırım \& Şimşek, 2008, p. 187).

\section{Population and Sample}

The research population consists of primary grade written children's books. And the sample includes 210 children's books which are written by both native and foreign writers, 
and published and sold by various bookstories in Turkish in Kırşehir. These books were chosen with the use of the random sampling method. 120 of these books were at second and third grade levels. These books were written in 16 type size; about one fourth consisted of colorful or black-and-white pictures and included, on average, 48 pages. The rest ( 90 books) were written in 14 type size and were fourth and fifth grade level; about one fourth consisted of colorful or black-and-white pictures and included 96 pages on average.

Table 1. The range of children's books based on publishers

\begin{tabular}{lcc}
\hline Publishers & n & \% \\
\hline Beş Renk & 80 & 38,1 \\
Mercek Çocuk & 30 & 14,3 \\
Pofuduk & 20 & 9,6 \\
Sedir (Erdem Çocuk) & 20 & 9,6 \\
Salan (Limon Kitap) & 20 & 9,6 \\
Duru & 10 & 4,7 \\
Ceren & 10 & 4,7 \\
Türev & 10 & 4,7 \\
Mutlu & 10 & 4,7 \\
Total & $\mathbf{2 1 0}$ & $\mathbf{1 0 0 , 0 0}$ \\
\hline
\end{tabular}

As shown in Table 1, 38.1\% of the examined children's books belong to Beş Renk Publishing; $14.3 \%$ to Mercek Çocuk Publishing; $28.8 \%$ to Pofuduk, Sedir and Salan Publishing and $18.8 \%$ to Duru, Ceren, Türev and Mutlu Publishing. Photographs of some of these books and book sets are presented in Figure 1.
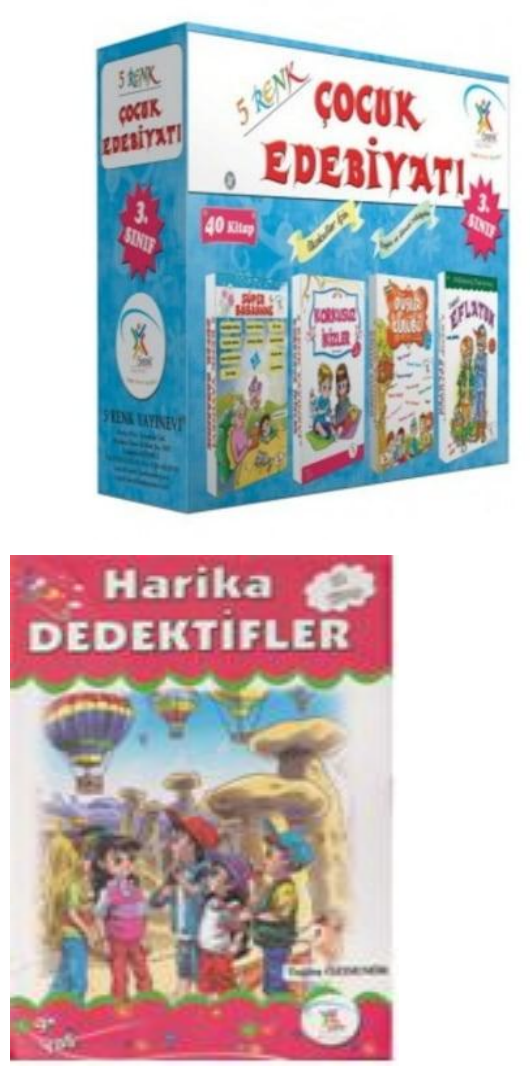
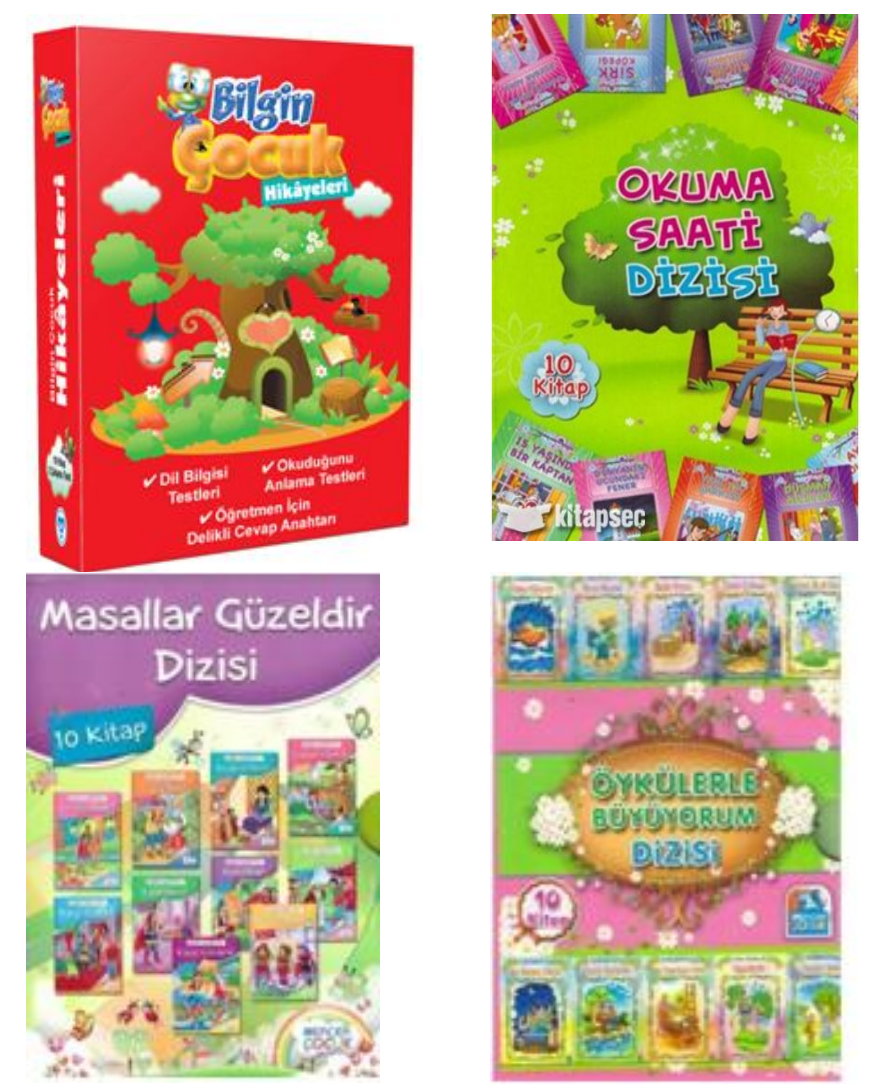

Figure 1. Books 


\section{Data Collection Tools}

The study data was collected through document analysis technique. According to Yıldırım and Şimşek (2008, p. 187) the document analysis technique which covers the examination of written materials about the goal phenomenon in research, "...can be the only data collection method in a study or it can be used together with other qualitative data collection methods." Following gathering the data, it was transferred to "Appraisal Form" which was developed by the researcher so as to determine the personal and social value contents of primary grade children's books.

The personal values in the study were limited to "being fair, humbleness, courage, generosity, diligence, devoutness, honesty, self-devotion, trust, love for animals, indulgence, goodness, valor, kindness, mercy, hospitality, modesty, loyalty, respect, love, responsibility, fidelity, truthfulness, frugality, morality, being tactful, cleanliness, being patient" and social values were limited as unity of "family, friendship, peace, being scientific, fellowship, cooperation, obeying rules, freedom, sharing, helpfulness, empathy, nature love and patriotism”.

\section{Data Analysis}

The data obtained through document analysis was analyzed and interpreted with the content analysis method.

\section{Findings}

Table 2. The range of values in children's books

\begin{tabular}{lcc}
\hline \multicolumn{1}{c}{ Values } & F & $\%$ \\
\hline Personal Values & 1200 & 74,2 \\
Social Values & 417 & 25,8 \\
Total & 1617 & 100 \\
\hline
\end{tabular}

Following the analysis, it was detected and demonstrated in Table 2, there were about 1,617 values found within these 210 primary grade children's books, $74.2 \%$ of which comprises the personal values while $25.8 \%$ were social values.

Table 3. The range of personal values in children's books

\begin{tabular}{clcc}
\hline Order No & Personal Values & f & \% \\
\hline 1 & Responsibility & 114 & 9,5 \\
2 & Love & 103 & 8,6 \\
3 & Goodness & 98 & 8,1 \\
4 & Diligence & 79 & 6,5 \\
5 & Courage & 78 & 6,5 \\
6 & Love for Animals & 72 & 6,0 \\
7 & Honesty & 67 & 5,5 \\
8 & Trust & 57 & 4,7 \\
9 & Mercy & 48 & 4 \\
10 & Respect & 46 & 3,8 \\
11 & Self Devotion & 45 & 3,7 \\
12 & Indulgence & 45 & 3,7 \\
13 & Kindness & 42 & 3,5 \\
14 & Hospitality & 39 & 3,2 \\
15 & Truthfulness & 39 & 3,3
\end{tabular}




\begin{tabular}{rlrc}
16 & Humbleness & 35 & 2,9 \\
17 & Valor & 31 & 2,5 \\
18 & Being Fair & 28 & 2,3 \\
19 & Generosity & 27 & 2,2 \\
20 & Fidelity & 26 & 2,2 \\
21 & Modesty & 18 & 1,5 \\
22 & Devoutness & 15 & 1,2 \\
23 & Morality & 14 & 1,2 \\
24 & Be Planned & 14 & 1,2 \\
25 & Loyalty & 13 & 1,1 \\
26 & Frugality & 4 & 0,3 \\
27 & Being Patient & 3 & 0,2 \\
28 & Cleanliness & 1 & 0,1 \\
Total & & $\mathbf{1 2 0 0}$ & $\mathbf{1 0 0 , 0}$ \\
\hline
\end{tabular}

As seen from the findings in Table 3 which refers to the personal values in the books, responsibility was the most commonly found value (114 times), followed by love (103 times), goodness (98 times), diligence (79 times) and courage (78 times). The least mentioned values in examined primary grade children's books were cleanliness (once), being patient (3 times) and being frugal (4 times).

Table 4. The range of social values in children's books

\begin{tabular}{clcc}
\hline Order No Social Values & f & \% \\
\hline 1 & Friendship & 111 & 15,5 \\
2 & Helpfulness & 101 & 14,1 \\
3 & Family Bonding & 91 & 12,7 \\
4 & Fellowship & 77 & 10,8 \\
5 & Sharing & 77 & 10,8 \\
6 & Cooperation & 66 & 9,2 \\
7 & Being Scientific & 57 & 8,0 \\
8 & Obeying Rules & 48 & 6,7 \\
9 & Freedom & 26 & 3,6 \\
10 & Nature love & 18 & 2,5 \\
11 & Peace & 14 & 1,9 \\
12 & Empathy & 14 & 1,9 \\
13 & Patriotism & 12 & 1,6 \\
Total & & $\mathbf{7 1 2}$ & $\mathbf{1 0 0 , 0}$ \\
\hline
\end{tabular}

Table 4 shows the findings related to social values in the examined primary grade children's books. Accordingly, the values of friendship (15.5\%), helpfulness (14.1\%) and unity of family (12.7\%) were among the most commonly found values, followed by fellowship $(10.8 \%)$, sharing $(10.8 \%)$, cooperation $(9.2 \%)$, being scientific $(8 \%)$ and obeying rules $(6.7 \%)$. The least mentioned values in the examined books were patriotism (1.6\%), empathy and peace $(1.9 \%)$ and love of nature $(2.5 \%)$.

\section{Results and Discussion}

Within the study context, 210 children's books which are written by native and foreign writers and published by various publishers, were examined in terms of social and personal values they include. The study results are as follows: 
The primary grade children's books commonly include these values respectively: responsibility, love, goodness, diligence, animal love and trust. And the least mentioned personal values in these books are respectively: cleanliness, being patient, frugality, loyalty, being tactful and morality.

In their studies, Şen (2008) about values in Turkish course books; Aktan and Padem (2013) and Aktan (2014) in Social Sciences and Turkish course books, they revealed that "love" was the most commonly addressed value. Similarly, Ekinci, Çelikpazu and Aktaş (2011) identified "love" and "diligence" as the most commonly addressed values. Deveci (2008) identified "diligence and trustworthiness;" Erdal (2009) identified "diligence, love of animals and goodness;" and Aral (2008) identified "love." Also, Aslan (2007) found that "responsibility" is the least addressed value in the books, which is not a consistent finding with this study.

The most commonly addressed values in primary grade children's books published by various publishers in Turkey are respectively: friendship, helpfulness and unity of family. On the other hand, the least mentioned values were respectively: patriotism, peace, empathy, love of nature and freedom.

Şen (2008) found that in the least mentioned values in Turkish course books were peace and unity of family. In this manner, the finding related to peace is consistent with the current study's results while results related to unity of family are contradictory with the study results. However Aktan and Padem (2013) indicated "peace" as the most commonly mentioned values while "unity of family" was the least mentioned value in their studies. Similarly, Aral (2008) emphasized "patriotism" as the least addressed value. These findings are inconsistent with the present study's findings. Also, in their studies, Aktan \& Padem (2013, 2014) suggested "freedom and patriotism" as the least addressed values in children's books. Likewise, Karatay (2011) identified "freedom" as the least addressed value. In their studies, Court and Rosental, (2007), Tosunoğlu and Kayadibi, (2006), and Zhang and Morrison, (2010) indicated a low rate of usage of "patriotism" in children's books. On the other hand, Dilmaç, Bozgeyikli and Çıkılı (2008) and Padem and Aktan (2014) determined "helpfulness"; Aslan (2007) "unity of family"; and Court and Rosental (2007) "friendship" as the most commonly dealt values in children's books, which are consistent with the study findings.

\section{Acknowledgements or Notes}

*This study was supported by the Ahi Evran University Scientific Research Projects Coordination Unit and the summary was presented in XI. European Conference on Social and Behavioral Sciences (2016).

\section{References}

Aktan, O. \& Padem, S. (2013). İlköğretim 5.sınıf sosyal bilgiler ders kitabında kullanılan okuma metinlerinde yer alan değerler [Values in the reading passages that are used in elementary school 5th grade social sciences textbook]. Asya Öğretim Dergisi [Asian Journal of Instruction] 1(2): 44-55

Aral, D. (2008). Millî Eğitim Bakanlığı'nın hazırladığg 6. sınıf Türkçe ders kitabında yer alan değerler üzerine bir araştırma [A research on the values taught in the Turkish language course book for the 6th grade prepared by the Ministry of National Education]. Master Thesis. Bolu, Turkey. 
Aslan, R. (2007). Öğretmen görüşlerine göre ilköğretim birinci basamaktaki öğrencilerin temel bilgi, beceri ve değerler kazanma düzeyleri. [ According to the teachers' opinions, the primary level of primary education strategy, basic knowledge, skills and values to gain levels] Master Thesis. Anadolu University, Eskişehir, Turkey.

Aslan, R. (2007). Öğretmen görüşlerine göre ilköğretim birinci basamaktaki öğrencilerin temel bilgi, beceri ve değerler kazanma düzeyleri [Levels of acquiring basic knowledge, skills and values of primary school children according to the viewpoints of their teachers]. Master Thesis. Anadolu University, Eskişehir, Turkey.

Bilgin, N., (2003). Sosyal psikoloji sözlüğü: kavramlar yaklaşımlar [Dictionary of social psychology: concepts, approaches]. İstanbul: Bağlam Publications.

Canatan, A. (2008). Toplumsal değerler ve yaşlılar [Social values and geriatrics]. Research Journal of Elderly Problems, (1), 62-71.

Carr D. \& Skinner D. (2009). The cultural roots of professional wisdom: Towards a broader view of teacher expertise. Educational Philosophy and Theory 41(2):141-154

Cevizci, A., (2002). Felsefe sözlügü [Dictionary of philosophy]. İstanbul: Paradigma Publications.

Cresswell, J. W. (2012). Educational research. Boston: Pearson Education.

Dilmaç, B. (2002). İnsanca değerler eğitimi [Humane values education]. Ankara: Nobel Publications.

Dilmaç, B., Bozgeyikli, H. \& Çıkılı,Y. (2008). Öğretmen adaylarının değer algılarının farklı değişkenler açısından incelenmesi [The Investigation of Teacher Candidates' Value Perceptions in Terms of Various Variables]. The journal of Value Education. 6(16): 69-91.

Edgington, D. W. (2002). To promote character education, use literature for children and adolescents. The Social Studies, 93 (3): 113-116

Ekinci Çelikpazu, E. Aktaş, E. (2011). Examination of texts at MEB 6, 7 and 8. Grade Turkish course textbooks according to value transmission. Turkish Studies International Periodical For The Languages, Literature and History of Turkish or Turkic 6(2) ss.. 413-422.

Erdal, K. (2009). Eğitim değerleri açısından çocuk kitapları [Child boks as to educational values]. Academic View, 17, 1-18.

Güleç, Ç. H. \& Gönen, M. (1997). The study of Turkish illustrated story books published between 1974-1993, from the viewpoint of physical aspects. Turkish Librarianship, $11(1), 42-53$.

Güleryüz, H. (2003). Yaratıcı çocuk edebiyatı [Creative children's literature]. Ankara: Pegem Akademi Publications.

Güngör, E. (1993). Değerler Psikolojisi Üzerine Araştırmalar. İstanbul: Ötüken Publication.

Halstead, M. \& Taylor, M. (2000).Learning and teaching about values: Areview of recent research. Cambridge Journal of Education, 30, (2).

Kan, Ç. (2009). Changing values and global citizenship education. Kastamonu Edcuation Journal, 17(3): 895-904.

Kluckohn, C. (1962). Values and value-orientations in the theory of action: An exploration in definition and classification. İn: Parsons, T, ve E. A. Shills, (eds). Toward a general theory of action, New York: Harper and Row Puplishers.

Kornblum, W., (1994). Sociology in a changing world. Harcourt Brace College Publishers.

Köknel, Ö., (2007). Çatışan değerlerimiz [Our conflicting values] İstanbul: Altın Kitaplar Publications.

Kutlu, S. (2011). Okul öncesi çocuk edebiyatı yapıtlarındaki resimlerin çocuğa göreliğinin öğretmen görüşlerine göre değerlendirilmesi (Eskişehir ili örneği)[ Evaluation of suitability of the pictures in the literary works written for the pre-school children for 
children considering the opinions of teachers: Sample of Eskişehir city]. Master Thesis, Ankara University, Ankara, Turkey.

Oğuzkan, F. A. (1998). İyi bir çocuk kitabı dil, anlatım, konu bakımından nasıl olmalıdır? M. R. Şirin (Haz.). 99 Soruda Çocuk Edebiyatı [Child Literature in 99 Questions] (ss. 210-212). Ankara: Çocuk Vakfi Publications.

Özgüven, İ. E. (1994). Psikolojik testler [Physchological tests]. Ankara.

Padem, S. \& Aktan O. (2014). Investigation of values in Turkish language books of elementary 5th grade. Düzce University the Journal of Social Science Institute, 2(21): $1-24$

Sever, S. (2007). Çocuk edebiyatı [Child literatüre]. Ankara: Kök Publications.

Sönmez, H. (2011). Reşat Ekrem Koçu'nun çocuklar için yazdığı eserlerde değer eğitimi ve Türkçe [Reşat Ekrem Koçus works which have written for children value education and Turkish]. Master Thesis. İnönü University, Malatya, Türkiye.

Şen, Ü. (2008). Investigation of 6th grade Turkish language books in a view of values. The journal of International Social Research, 1(5) 763-779.

Şirin, M. R. (2007). Çocuk edebiyatı kültürü [Culture of child literatüre]. Ankara: Kök Publications.

Temizyürek, F. (2003). Türkçe öğretiminde çocuk edebiyatının önemi [Importance of child literature in teaching Turkish]. TÜBAR-XIII, 161-167.

Theodorson, G.\& Theodorson A.A., (1969). Modern dictionary of sociology, New York and London: Barnes \& Noble Publishers.

Tür, G. \& Turla, A. (1999). Okul öncesinde çocuk, edebiyat ve kitap [Child literatüre and book in early childhood]. İstanbul: Ya-Pa Publications.

Yıldırım, A. \& Şimşek. H. (2008). Sosyal bilimlerde nitel araştırma yöntemleri[Qualitative research methodologies in social sciences]. Ankara: Seçkin Publications.

Yıldırım, K. (2009). Values education experiences of Turkish class teachers: A phenomenological approach. Eurasian Journal of Educational Research, 35,165-184.

Y1lmaz, M. (2003). Learning method and value education. The Journal of Value Education. 2, $120-129$ 